\title{
Influence of melasses non-sugars on efficiency of fermentation of mash from sacchariferous raw material
}

Koval O.', Oliinichuk S. ${ }^{2}$

Institute of food resources of NAAS, Ye. Svers-tiuk Str., 4a, Kyiv, 02002, Ukraine; e-mail: 1'olgakoval1982@gmail.com, ${ }^{2}$ oliynichukst@ukr.net

The purpose. To establish influence of melasses non-sugars on physiological activity of yeast and efficiency of fermentation of mash from sacchariferous raw material. Methods. Determination of physical and chemical structure of sacchariferous raw material, parameters of mash and mature distillers' beer spent according to techniques which are used in production of sugar and spirit. Statistical. Results. At decrease of melasses share in nutrient medium the general high quality of a mash raises, concentration of dry substances in it decreases, reducing thus osmotic stress of cells of yeast, and, accordingly, charges of sugars on glycerin production. Reduction of non-sugars in a mash at replacement of melasses sugars with sugars of diffusion juice promotes on 25 and $50 \%$ greater accumulation of spirit in distillers' beer, increases biomass in it and decreases parameter of non-fermented sugar. Increase in a share of sugars of diffusion juice in a mash up to $75 \%$ actually levels negative influence of melasses non-sugars on ability to live of yeast cell. Replacement of a part of melasses sugars with sugars of juice increases output of ethanol that enables in addition to receive 1,24 $-2,29$ dal on each ton of raw material of this quality. Conclusions. It is established that melasses non-sugars negatively influence growth of yeast biomass and its alcohol-forming ability. Decrease in non-sugars in a mash because of replacement of melasses sugars with sugars of diffusion juice improves parameters of quality of mature distillers' beer. Normative output of spirit from saccharose is reached at fermentation of diffusion juice with high quality of $84,9 \%$. The highest effect of processing melasses of this quality can be reached by its mixing with diffusion juice in a proportion 25:75.

Key words: non-sugars, diffusion juice, fermentation, melasses, Saccharomyces cerevisiae, bioethanol, yeast.

DOI: https://doi.org/10.31073/agrovisnyk201903-10

Introduction. The economic feasibility of use of sugar beet processing products as feedstock for bioethanol production was proved by both domestic and foreign scientists [1-5]. The integration of bioethanol production into the structure of a sugar plant is successfully used in several countries of the world. Thus, one of Europe's largest producers is Bazancourt-Pomacle Biorefinery (France), is based on the Crystal Union sugar plant and the ethanol production Cristanol [6].

Enterprises of a similar design are being established and operate in Ukraine. However, the efficiency of such process is significantly reduced due to the use at the sugar factories of a three-product sugarproduction layout aimed at maximizing the profit of the sugar compartment, which negatively affects the quality of molasses, increasing the content of harmful non-sugars in it, and, accordingly, decreases the economic performance of bioethanol production. In this regard, the use of such molasses in the production of bioethanol requires adjustment of technological parameters of their processing to minimize negative effects of an increased quantity of non-sugars, in particular melanoidins, caramelans etc., on the viability of the yeast cell.

The purpose of research is to determine the influence of molasses' non-sugars on physiological activity of yeast and the efficiency of fermentation of wort from sugar-containing raw materials.

Materials and methods. The wort based on raw diffusion juice, molasses and their mixtures, the process of yeasts cultivation and fermentation, matured wort were the objects of research.

As a producent of ethanol the yeasts' Saccharomyces cerevisiae strain K-7 (Y 5007) was used, which can ferment molasses-based wort with concentration of dry matter $26-28 \%$ and ethanol accumulation in the mature wort within $10-11 \%$ vol. The strain is characterized by high alcohol-forming ability and economy of ethanol synthesis [7]. 
The cultivation of yeasts and wort fermentation was carried out within the parameters used on the refinery. The control of the fermentation process was carried out by the amount of $\mathrm{CO}_{2}$ released during fermentation.

The physicochemical composition of sugar-based feedstocks, quality indicators of wort and mature wort were analyzed according to the methods used in sugar and ethanol production [8-13].

All the experimental trials were conducted in triplicate sets. Results shown in tables and figures represent average values.

Results. The physicochemical composition of samples received from industrial-technological process in 2016 - 2017 - raw diffusion juice and molasses - was investigated for their alcoholic fermentation eligibility (Table 1).

Received data give a reason to affirm the sufficient amount of usable sugars in these types of raw materials and possibility of their fermentation into bioethanol. But molasses received from industrialtechnological process has the characteristic of "defective" [9] that significantly affects for efficiency of its fermentation by yeasts cells.

Table 1. Physicochemical composition of sugar-containing raw materials received from refinery

\begin{tabular}{|c|l|c|c|}
\hline \multirow{2}{*}{ № } & \multicolumn{1}{|c|}{ Characteristic } & \multicolumn{2}{|c|}{ Result of analysis } \\
\cline { 3 - 4 } & \multicolumn{1}{|c|}{ Diffusion juice } & Molasses \\
\hline 1 & Concentration of dry matter (DM)\% & 18,25 & 80,00 \\
\hline 2 & pH of the medium & 5,36 & 5,68 \\
\hline 3 & Content of sucrose, \% & 15,60 & 45,50 \\
\hline 4 & $\begin{array}{l}\text { Content of reducing substances (Muller } \\
\text { reactive), } \%\end{array}$ & 0,83 & 1,70 \\
\hline 5 & Total amount of fermentable sugars, \% & 15,50 & 46,40 \\
\hline 6 & Content of total nitrogen, \% & 1,20 & 1,25 \\
\hline 7 & Content of amine nitrogen, \% & $\mathrm{n} / \mathrm{a}$ & 0,21 \\
\hline 8 & $\begin{array}{l}\text { Coloration value, \% to light transmission } \\
\text { of distilled water }\end{array}$ & $\mathrm{n} / \mathrm{a}$ & 2,67 \\
\hline 10 & Purity, \% & 84,93 & 58,00 \\
\hline
\end{tabular}

Our opinion, one of possible reasons of molasses ' quality deterioration is high content of saponin in second and third massecuite of sugar production, which caused intensive foam formation in them and increased duration of boiling. Under such conditions the content of invert sugar was increased, which decomposition is followed by formation of apoglucinic and other acids that are inhibitors of yeasts.

The molasses received from sugar refinery have a low coloration value $-2,67 \%$ against $40 \%$, as defined by Typical Regulation [9], which is caused by the significant content of melanoidins formed in the process of Maillard reaction. Melanoidins are quite significant inhibitors of yeasts since they absorb on the surface of yeast cells, especially at low pH values, what impede access of nutrients into the cell and inhibit its enzymatic activity [14]. In the process of fermentation of such molasses, mature wort was characterized by a low content of yeast biomass and a significant excess of non-fermented sugar content, which confirms the negative effect of the abovementioned molasses indicators.

The investigation of molasses' non-sugars influence on the enzyme system of yeasts was carried out by replacing the part of molasses sugar with raw diffusion juice sugar, since previous studies [15] have established a positive effect of blending of intermediates of sugar production as feedstock for bioethanol production. As a control variant, the wort based on sugar beet molasses was used. Other variants of the research included the replacement of the part of sugar of molasses by the equivalent of sugar of diffusion juice in various ratios. The duration of fermentation was 72 hours, for control variant -80 hours. The distribution of dry matter content in the wort when molasses are replaced with juice is shown in Figure 1. 


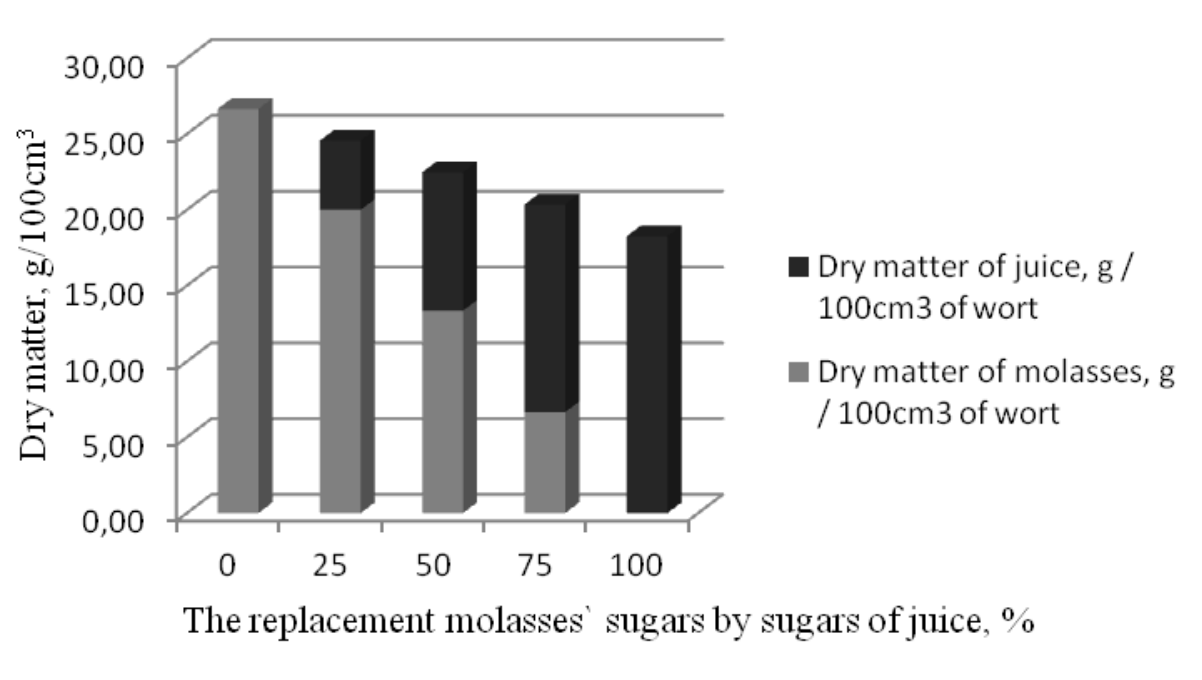

Figure 1. The ratio of the dry matter content of molasses and diffusion juice in sugarcontaining wort

It should be noted that the content of dry matter in the wort decreases with the increase of content of sugar of juice in it, since this type of raw material has a higher purity value $(84.93 \%)$ compared to molasses $(58.00 \%)$, and consequently, the equivalent amount of sugars corresponds to less amount of non-sugars, which may affect the vital activity of the yeast cells. One of the indicators of such influence is the increase in the amount of yeasts biomass with an increase in the proportion of diffusion juice in the wort (Table 2) - by $4.14 \%-31.72 \%$ compared to control. Given the published data $[14,16]$ about negative impact of melanoidins on the functioning of the yeast cells it can be argued that just high quantity of molasses' nonsugars, including melanoidins, in the wort is the reason of a reduction in the biomass content in mature wort with the decrease of juice part in the initial wort.

Table 2. The influence of non-sugars of molasses on the efficiency of fermentation of sugar-containing wort

\begin{tabular}{|c|c|c|c|c|c|}
\hline \multirow{2}{*}{ Characteristic } & \multirow{2}{*}{$\begin{array}{l}\text { Control } \\
\text { (molasses) }\end{array}$} & \multicolumn{4}{|c|}{$\begin{array}{c}\text { The replacement molasses` sugars by sugars of } \\
\text { juice, } \%\end{array}$} \\
\hline & & $\begin{array}{c}25 \\
\text { (var.1) }\end{array}$ & $\begin{array}{c}50 \\
\text { (var. 2) }\end{array}$ & $\begin{array}{c}75 \\
\text { (var. 3) }\end{array}$ & $\begin{array}{c}100 \\
\text { (var. 4) }\end{array}$ \\
\hline $\mathrm{pH}$ of mature wort & 5,04 & 5,00 & 4,96 & 4,75 & 4,10 \\
\hline The content of ethanol, \% vol. & 9,05 & 9,55 & 9,65 & 9,80 & 9,80 \\
\hline $\begin{array}{l}\text { The content on non-fermented sugar, } \\
\mathrm{g} / 100 \mathrm{~cm}^{3}\end{array}$ & 1,04 & 0,40 & 0,35 & 0,26 & 0,23 \\
\hline The biomass, $\mathrm{g} / \mathrm{dm}^{3}$ & 14,50 & 15,10 & 18,60 & 18,70 & 19,10 \\
\hline The content of glycerol, $\mathrm{g} / 100 \mathrm{~cm}^{3}$ & 1,18 & 1,10 & 0,98 & 0,90 & 0,90 \\
\hline
\end{tabular}

Influences by high-osmolar media, S. cerevisiae cells react by rapid intracellular accumulation of glycerol to counteract their dehydration [17]. Consequently, a decrease of dry matter concentration in a wort helps to reduce the accumulation of glycerol in mature wort, as evidenced by the data of Table 2 .

The reduction of non-sugars content in the wort by introducing juice in it positively affects generating ability of yeasts and accumulation of ethanol in the mature wort. Thus, if only $25 \%$ of sugars of molasses are replaced with sugars of juice, the ethanol content in the mature wort increases by $5.53 \%$, with the replacement of $75 \%$ of sugars - by $8.29 \%$ compared to the control corresponding to the ethanol content obtained with the complete replacement of molasses by diffusion juice.

The fermentation of wort of control variant is characterized by high content of non-fermented sugar $1,04 \mathrm{~g} / 100 \mathrm{~cm}^{3}$ (Table 2) which is 4.5 times higher than in variant $4\left(0,23 \mathrm{~g} / 100 \mathrm{~cm}^{3}\right)$, which also reflecting the negative impact of high content of non-sugars on enzymatic activity of the yeast cells. 
In the process of vital activity yeast cells produce organic acids that affect the indicator of active acidity. For optimal functioning of yeast, the initial $\mathrm{pH}$ of the wort in all variants was 4.80 , but in fermented wort of variant 4 , this indicator decreased to 4.10 , which is explained by the small buffering of diffusion juice. Increase of part of molasses in the nutritive medium stabilized the $\mathrm{pH}$ index at $4.75-5.04$, since the presence of more quantity of salts, especially phosphates, in it, facilitates to rising medium buffering and increases the propensity for glycerol production through higher $\mathrm{pH}$ and that most salts act as triggers of osmotic stress.

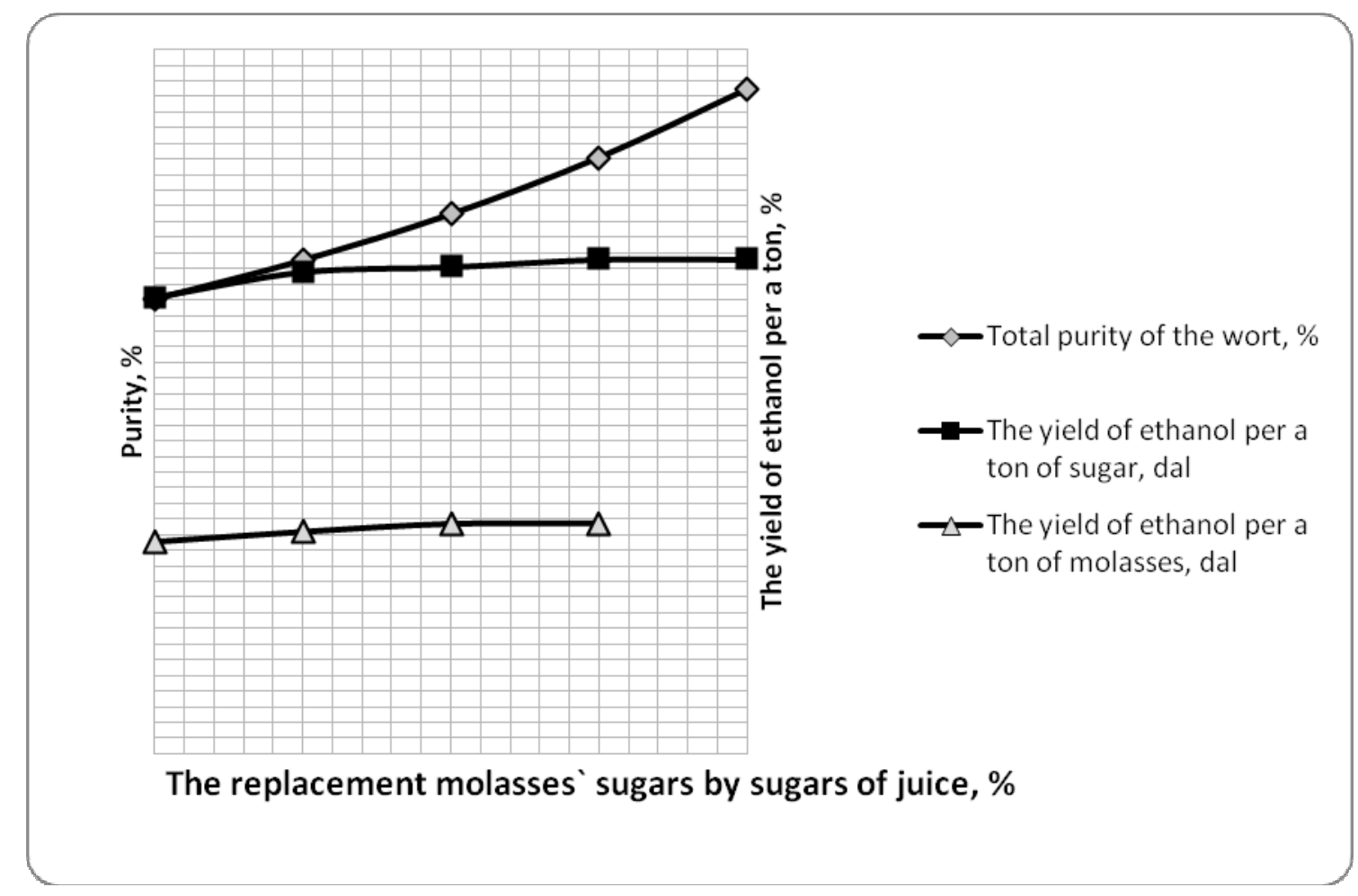

Figure 2. The addiction of ethanol yield per ton of input sugar and per ton of molasses from total purity of the wort

With the decline of part of molasses in nutritive medium total purity of the wort increases - up $46.04 \%$ when complete replacement of sugar of molasses by sugars of juice, compared with the control. The yield of ethanol per ton of input sugar is 63.23 dal, which corresponds to norms of production. However, it should be noted that the yield of ethanol per ton of sugar in variant 3 ( $75 \%$ replacement) is similar under lower purity of the wort (Figure 2). It is possible that such quantity of non-sugars of molasses doesn't have explicit negative effect on cells, besides availability of additional nutrients which are in the raw diffusion juice at the medium can particularly level influence of non-sugars on the yeasts. It is possible that such quantity of non-sugars of molasses doesn't have explicit negative effect on cells, furthermore availability of additional nutrients, which are in the raw diffusion juice, at the medium can partially reduce influence of non-sugars on the yeasts. In general, the introduction of diffusion juice in different proportions contributes to an increase of the yield of ethanol per ton of input sugar at the level of $4.56-8.42 \%$ compared with control, which reduces production losses.

One of the important indicators in the production of ethanol is the yield of ethanol per a ton of raw materials. As can be seen from Figure 2, the replacement of sugars of molasses by sugars of juice increases the yield of ethanol to $28.40-29.45 \mathrm{dal} / \mathrm{t}$, with $27.16 \mathrm{dal} / \mathrm{t}$ in control variant, which allows additionally to obtain 1.24-2.29 dal per every ton of raw materials of such quality.

\section{Conclusions}

It was determined that molasses' non-sugars have a pronounced negative effect on the rate of biomass growth of yeasts and their alcohol-forming ability. Reducing the content of non-sugars in the wort by 
replacing sugars of molasses with diffusion juice sugars contributes to a greater accumulation of ethanol in fermented wort, an increase the content of biomass in it and a decrease non-fermented sugar content.

The normative yield of ethanol from sucrose is achieved by fermentation of diffusion juice with a purity of $84,9 \%$. Reducing the part of sugars of diffusion juice in a nutritive medium below $75 \%$ of the total input sugar reduces the yield of ethyl alcohol. The highest effect of the processing of molasses of this quality can be achieved by mixing it with diffusion juice in the proportion of 25:75.

\section{References}

1. Zubchenko V., Hrushytskyi M., Tkachenko L. (2008). Vykorystannia napivproduktiv tsukrovoho vyrobnytstva yak alternatyvnoi syrovyny dlia oderzhannia bioetanolu Use of semiproducts of sugar production as an alternative raw material for bioethanol production. Kharchova promyslovist. Food Industry. 7. P. 12-14. in Ukrainian.

2. Kaletnik H. (2010). Biopalyvo: prodovolcha, enerhetychna ta ekolohichna bezpeka ukrainy: monohrafiia. Biofuels: food, energy and ecological safety of Ukraine: monograph. Kyiv: Khai-Tek Pres. 516 p. in Ukrainian.

3. Ivanov S. V., Sychevskyi M. P., Oliynichuk S.T., Yarchuk M. M., Kalinichenko M. F., Sosnytskyi V. V., Lukashevych Ye. A., Khomichak L. M., Shyian P. L., Rudakov V.K. Patent. 86054 Ukraina, MPK (2013.01) C10L 1/00, S13V 99/00. Sposib vyrobnytstva tsukru ta bioetanolu. Method of producing sugar and bioethanol; Applicant and Patent Attorney National University of Food Technologies, Research and Production Limited Liability Company Intermash, Institute of Food Resources of the National Academy of Agrarian Sciences of Ukraine. u20130777; stated. 19.06.13; Bjul. 10.12.13. 2 p. in Ukrainian.

4. Ramesh Duraisam, Ketemaw Salelgn, Abiyu Kerebo Berekete. (2017). Production of beet sugar and bio-ethanol from sugar beet and it bagasse: a review. International Journal of Engineering Trends and Technology. Vol. 43. 4. P. 222-233. doi.org/10.14445/22315381/IJETT-V43P237

5. Bowen E., Kennedy S. C., Clark W. M. (2010). Ethanol from sugar beets : a process and economic analysis. Worchester Polytechnic Institute. 143p. https://web.wpi.edu/Pubs/E-project/Available/E-project042810-165653/unrestricted/Ethanol_from_Sugar_Beets_-_A_Process_and_Economic_Analysis.pdf

6. Schieb, P.-A., Lescieux-Katir, H., Th not, M., Cl ment-Larosi re, B. (2015). Biorefinery 2030. Biorefinery 2030: Future Prospects for the Bioeconomy. Berlin, Heidelberg: Springer Berlin Heidelberg. 123p. doi.org/10.1007/978-3-662-47374-0

7. Oliynichuk S. T., Tkachenko A. F., Shevchenko V. I., Koval K.O., Rudnichenko L. V., Shustikova N. Ye. Patent 20915 Ukraina, MPK S12N, C12P, C12R 1/865 Hibrydnyi shtam drizhdzhiv saccharomyces cerevisiae meyen dlia mikrobiolohichnoho syntezu spyrtu z meliasy. Hybrid strain of yeast Saccharomyces cerevisiae Meyen for microbiological synthesis of alcohol from molasses; Applicant and Patent Attorney Ukrainian Research Institute of Alcohol and Biotechnology of Food Products. 96124751; stated. 20.12.96; Bjul. 15.12.00. 2 p. in Ukrainian.

8. DSTU 3696-98 (HOST 30561-98). (1998). Meliasa buriakova. Tekhnichni umovy. Beet molasses. Specifications Kyiv. 10 p. in Ukrainian.

9. TTR 000 32744-3508-2005. (2005). Typovyi tekhnolohichnyi rehlament oderzhannia meliasnospyrtovoi brazhky i presovanykh khlibopekarskykh drizhdzhiv. Typical technological regulations for the production of molasses-alcohol fermented wort and pressed baking yeasts. Kyiv. 246 p. in Ukrainian.

10. Buhaenko Y.F. (1989). Tekhnokhymycheskyi kontrol sakharnoho proyzvodstva. Technochemical control of sugar production. Moskva: Ahropromyzdat, 1989. 216p. in Russian.

11. Rukhliadieva A.P. (1974). Tekhnokhymycheskyi kontrol spyrtovoho proyzvodstva. Technochemical control of alcohol production. Moskva: Pyshchevaia promishlennost, 1974. 208 p. in Russian.

12. Boiko L.M. (1986). Fyzyko-khymycheskye metodi kontrolia brodylnikh proyzvodstv. Physicochemical methods of controlling fermentation productions. Kyev: Tekhnyka. 192 p. in Russian.

13. Kupchyk M. P., Reva L. P., Shtanheieva N. I., Cherniavska L.I., Lipiets A.A., Khomichak L.M. .... Nychyk O.V. (2007). Tekhnolohiia tsukrystykh rechovyn. Laboratornyi praktykum. Technology of sugarcontaining substances. Laboratory Workshop. Kyiv: NUKhT. 393 p. in Ukrainian.

14. Marynchenko V. O. Domaretskyi V.A., Shyian P.L., Shvets V.M., Tsyhankov P.S., Zholner I.D. (Ed. 
Marynchenko V. O.). (2003). Tekhnolohiia spyrtu: pidruchnyk. Alcohol technology: textbook. Vinnytsia : Podillia-2000, 2003. 496 p. in Ukrainian.

15. Koval O. O., Oliynichuk S.T., Khomichak L.M., Lysak T.I., Batoh Yu.O. (2014). Zbrodzhuvannia tsukrovmisnykh produktiv tsukrovoho vyrobnytstva $v$ bioetanol. Fermentation of sugar-containing products of sugar production into bioethanol. Tsukor Ukrainy. Sugar of Ukraine. 2 (98). P. 10-13. in Ukrainian.

16. Domaretskyi V. A., Prybylskyi V. L., Mykhailov M. H. (Ad. Domaretskyi V.A.). (2005). Tekhnolohiia ekstraktiv, kontsentrativ i napoiv iz roslynnoi syrovyny: pidruchnyk. Technology of extracts, concentrates and beverages from plant raw materials: textbook. Vinnytsia: Nova knyha, 408 p. in Ukrainian.

17. Nevoigt E., Stahl, U. (1997). Osmoregulation and glycerol metabolism in the yeast saccharomyces cerevisiae. FEMS Microbiology Reviews. Vol. 21. Issue 3. P.231-241. doi.org/10.1111/j.15746976.1997.tb00352.x 